\title{
Artelogie
}

Recherche sur les arts, le patrimoine et la littérature de l'Amérique latine

$15 \mid 2020$

Latin American networks: Synchronicities, Contacts and Divergences.

\section{Geometry and movement, Latin Americans in the International Art Network}

\section{Maria Cristina Rossi}

Translator. Jane Brodie

\section{OpenEdition \\ Journals}

Electronic version

URL: http://journals.openedition.org/artelogie/4444

DOI: $10.4000 /$ artelogie.4444

ISSN: 2115-6395

Publisher

Association ESCAL

Electronic reference

Maria Cristina Rossi, «Geometry and movement, Latin Americans in the International Art Network », Artelogie [Online], 15 | 2020, Online since 08 April 2020, connection on 05 August 2020. URL : http:// journals.openedition.org/artelogie/4444

This text was automatically generated on 5 August 2020.

Association ESCAL 


\title{
Geometry and movement, Latin Americans in the International Art Network
}

\author{
Maria Cristina Rossi
}

Translation : Jane Brodie

\section{THE CONCRETE AVANT-GARDE'S MOMENT}

\section{Brief Introduction to the Heroic Period}

1 The summer of 1944, remembered so often and well as the summer when Arturo. Revista de Artes Abstractas was published, was a key moment in the disputes between dominant and emerging aesthetics in the Rio de la Plata. Pierre Bourdieu points out that:

[...] For bold strokes of innovation or revolutionary research to have some chance of even being conceived, it is necessary for them to exist in a potential state at the heart of the system of already realized possibles [...] Moreover, they must have some chance of being received, meaning accepted and recognized as 'reasonable', at least by a small number of people, the same ones who would no doubt have been able to conceive of them. (BOURDIEU, 1995: p. 349

Indeed, during the final years of World War II young people were intensely enthusiastic about the advances of science and technology-largely driven by the war machine-but also mobilized by the historical trauma left by a string of international conflicts (the harshening of fascism in various forms, the Spanish Civil War, and-of course-World War II itself). That context also brought politicization; young people participated in student organizations, political parties, and anti-fascist leagues.

The avant-garde vision of some of the artists who founded the magazine Arturo ${ }^{1}$ was coupled with dissatisfaction with the art education system. In spring of 1942, Tomás Maldonado, Claudio Girola, Alfredo Hlito, and Jorge Brito signed the "Manifiesto de cuatro jóvenes," in which they not only repudiated the system by which awards were granted at the Salón Nacional, but also their teachers who had acted as jurors for that 
prize or won it themselves. The group tried to engage the student body as a whole in their protest against the art education system, but that did not happen. Those four artists grew more and more radical, and eventually dropped out of the academy (ROSSI, 2010a). In that framework, the publication of Arturo. Revista de artes abstractas in April of 1944 was key to shaking up the dominant aesthetic. While there had been an earlier debate on abstraction in the Argentine art field around the Primera exposición de Dibujos $y$ Grabados Abstractos in 1936, abstraction was still little known, not well enough to give rise to opposition. Indeed, that earlier discussion was limited to an exchange of opinions between critics Julio Rinaldini and Attilio Rossi.

In the mid-forties, things were different. The magazine Contrapunto was a crucial forum of debate. It published "Defensa del Realismo" written by Communist intellectual Héctor Agosti, as well as an article critical of Agosti's defense by Raúl Lozza. In April 1945, the magazine published a survey entitled “ ¿Adónde va la pintura?" [Where is Art Headed?] that aggravated differences. In this fraught atmosphere, groups of concrete artists took a stance. They formulated their proposals in avant-garde terms and engaged in essential avant-garde practices: writing manifestos, handing out leaflets, and engaging in controversial actions to spread their ideas in, among other places, the Argentine Communist Party's newspaper (many of these artists belonged to the Party).

Concrete artists from the Rio de la Plata opposed their art of "invention" to mimetic art, holding "presentation" over representation. The Asociación Arte Concreto Invención $(A A C I)^{2}$ and the MADI ${ }^{3}$ grew out of the Arturo group. Founded in 1946, both groups embraced the idea of the cutout frame and, later, produced what they called "coplanar" works. The Madí artists not only explored the possibilities of irregular formats, but also made articulated and manipulatable paintings and sculptures where viewers could change the work's form.

6 The AACI was committed to surrounding people with "real things." They held that if people got used to relating to things directly, rather than to their "fictions," they would be moved to take "action"-a key mission of their communist ideology. These artists invented forms based on geometric shapes painted in flat colors. They made use of cutout formats and, later, began placing two-plane forms directly on the wall (though these works were articulated, they were not manipulable-each one was set in a final position once the right shape had been obtained).

7 In 1947, those groups formally splintered, though a process of expansion and regrouping had begun earlier. The submissions to the Arte Nuevo salon that year evidenced a growing number of artists interested in the language of abstraction. Some salons-the Salón de Otoño organized by the Sociedad Argentina de Artistas Plásticos (SAAP) and the Salón de Nuevas Realidades of 1948, for instance-brought together novel works by young artists. Furthermore, by 1948 the reconstruction of Europe was far enough along so that Argentine artists could once again think about visiting museums and artists' studios there. The first one to do so was Tomás Maldonado. He was followed by Carmelo Arden Quin, Juan Melé, and Gregorio Vardanega. ${ }^{4}$

8 This renewed international exchange got underway at the same time that the Soviet Union was demanding realignment under the canon of realism. That certainly heated up the debates on aesthetics within the Argentine Communist Party, and ultimately led to the end of the tolerance that had been enjoyed by the concrete artists. While many different factors contributed to the dispersion of the concrete artists and their various groups, this latest rupture-for those who considered it primordial to join political and 
aesthetic transformation-served not only to deepen the breaches in the alreadyfractured groups, but also to close the heroic period (1945-48).

\section{Connections in the Period of Expansion}

9 The first Salón de Arte Nuevo was held in late 1947. Issued on the occasion of the show was a group declaration expressing the desire to join together the various groups of young artists in a joint action geared to forging a broader movement. ${ }^{5}$ It is necessary to capture this framework, and how the concrete vision expanded and diversified under it, to be able to understand the exchanges that ensued after the heroic period as tactics and strategies that the artists devised to expand the modest space of circulation gained thus far. At the same time, it is also important to recognize that that expansion also brought greater flexibility to the concrete avant-garde agenda.

Looking to Michel de Certeau, we might think of tactics as the actions of those who did not have a base of their own (an organization, say) but who acted in the field of others; strategies, on the other hand, were developed by those with contacts capable of legitimizing and spreading initiatives undertaken from their existing bases of operation (CERTEAU, 2001: pp. 391-425). This wider movement of the nineteen-fiftiesa sort of "expanded field of abstract painting"-was composed by all the previous explorations, from concrete art and MADI to free, lyrical abstraction based on geometric art or informalism. They all contributed to consolidating the abstract language while also, naturally, developing their specific strains within the abstract movement.

11 It was in the framework of that movement that José Mimó Mena-who had participated in the 1948 Salón de Otoño, which also featured works by Melé, Villalba, Enio Iommi, Nélida Fedullo, Jorge Souza, and Vardanega-traveled to Venezuela. Interested in concrete art, he took with him works by the artists mentioned, which would be exhibited alongside his own at the Taller Libre de Pintura (the show opened on October $24,1948)$. That Taller had been created at the initiative of students who, dissatisfied with the instruction at the Escuela de Arte Plástica y Artes Aplicadas in Caracas, attempted to break with the reigning figurative canon. ${ }^{7}$ On October 25 , the day after the opening, Caracas-based newspaper Noticias Gráficas commented on the originality of the works and to what extent the artists had been able to attract public attention. ${ }^{8}$ The catalogue text affirmed:

[...] we have here what we have invented thus far: abstract works by José Mimó Mena, concrete works by Argentine artists-just a small sample of many. In them you will not find masterful brushstrokes, perhaps only a modicum of skill. What you will find are inventions for our times. In them, you will not find sorrow. We paint with youth and joy. We don't do anything dramatic-we are scared of monsters. For a happy civilization, we make cheerful painting. ${ }^{9}$

Bélgica Rodríguez underscored the importance of this exhibition for young Venezuelan artists "waiting their turn to go to Paris" (RODRÍGUEZ, 1979). Adolfo Wilson argued that, insofar as the first exhibition of abstract art in Venezuela, it was a crucial event (WILSON, 2007: pp. 153-57). In his memoir, Melé recounts that Mimó Mena took home a work of his authorship along with others by Hlito, Fedullo, Souza, and Del Prete. In a conversation many years later, Melé asked Venezuelan artist Alejandro Otero if he knew Mimó Mena. Otero said that not only did he know him, he had worked with him on that show (MELÉ, 1999: pp. 126-30). 
13 In a recent interview with Carlos Cruz Diez, though, the historic importance of that show is relativized. Ariel Jiménez points out that neither the testimony of the artists involved nor the existing historiography places that exhibition before the one of Otero's Las cafeteras [Coffee Pots], and that that show was the one that really produced a radical shift in his generation. Jiménez holds that what drove the abstract turn in Venezuela was "work produced by a Venezuelan from Europe [...] who, because of the process of historical legitimation in effect at the time, looked to Europe, just as Argentines did. Real legitimacy came from there and nowhere else" (JIMÉNEZ, 2010: pp. 157-8).

Though it is not my intention here to propose a chain of influences, I believe that that show in which Mena participated is a significant link. It broke into the transformation underway in the Venezuelan art field not only through the works themselves but also through the modes of action of the Rio de la Plata avant-garde, with the jubilant message expressed in many of the manifestos issued in the immediate wake of World War II.

Rather than lay out a chronological sequence, I am interested in pointing out that these networks of exchange brought together desires and expectations capable of producing new proposals-that regardless of the reticence of centers of legitimation to communicate these new productions.

16 The proximity of the Mimó Mena and the Otero exhibitions suggests, following Bourdieu, that the ruptures effected by concrete art could be received, accepted, and recognized as "reasonable," at least by those who conceived of those ruptures. In taking another look at these networks, though, it appears that the advent of the "Argentine delegation" was largely the result of Mimó Mena's personal initiative, as opposed to a joint strategy. Indeed, in Melé's own testimony, he states that his artistic development was thrown off by the contact with Venezuela. In any case, that first tie to Venezuela was strengthened by contacts with artists in Paris, especially Madí artists.

The correspondence, in early 1948, between Gyula Kosice and Félix Del Marle, the Secretary of Réalites Nouvelles, attests to how hard Gyula Kosice tried to penetrate the Parisian circuit. Answering a letter from Kosice, Del Marle states:

votre groupe MADI est connu á présent à Paris car j'ai distribué, là où il fallait, vos papiers de propagande très intéressants. On s'intéresse ici beaucoup á vos efforts $[\ldots]^{10}$

18 He also says that though it was not possible to organize an exhibition of the Madí group, it could have a gallery at annual salon held at the Palais de Beaux Arts. Thus, ten Madí artists were featured in the 3ème. Salon de Réalités Nouvelles. According to critic Pierre Descargues, their works were "the foreign oddity" that made painting explode. ${ }^{11}$

The following year, the 1re Exposition des Artistes d'Amérique-Latine à Paris featured works by Vardanega, Melé, and Arden Quin, as well as by Venezuelan abstract artist Mateo Manaure. During this period, Arden Quin established other ties in Paris and, ultimately, founded a group (its members were Peruvian artists Bresciani and Jorge Eielson, and French artists Desserprit, Chaloub, Guy Lerein (DE MAISTRE, 1996: pp. 43-58)). In addition to Manaure, Arden Quin met Luis Guevara Moreno who, in 1951, introduced him to a larger group of Venezuelans, specifically Otero, Carlos González Bogen, Rubén Nuñez, Pascual Navarro, Peran Erminy, Aimée Nattistini, Dora Hersen, and Narciso Debourg-all of them involved, to varying degrees, in the magazine Los disidentes. Out of those contacts, and the shared interests to which they gave rise, emerged what was 
known as the international Madí movement, in which Núñez and Guevara also participated (WILSON, 2007: pp. 153-57).

Publications were privileged channels of dialogue between Latin American artists. While there is not room here to discuss the full richness of those interchanges, I will discuss the specific ties that arose through those broader networks. Because he sat on the editorial board of a number of magazines, Raúl Lozza came into contact with Uruguayan and Brazilian artists. Starting in early 1946, he corresponded with Hans Platschek-a German artist who produced abstract work in Montevideo-and with Sarandy Cabrera-an incisive member of the Taller Torres García. Starting in mid-1947, he and Brazilian writer Marques Rebelo exchanged letters (ROSSI, 2010b). Lozza's "Open Letter to M. Lobato" circulated in the Curitiba-based magazine Joaquim (GARCÍA, 2011: pp. 143-152).

The contacts between artists from Río de la Plata and Brazil were furthered by the relationship between Juan Carlos Paz and Hans Joachim Koellreutter, a Rio de Janeirobased avant-garde musician who composed, in 1940, the twelve-tone work Invención (Invention). After visiting Buenos Aires and Montevideo, Koellreutter wrote to Kosice in 1950. That letter evidences an earlier exchange of ideas on the possibility of composing music without counterpoint, harmony, theme, or imitation. Koellreutter writes that atonal and twelve-tone music could pave the way for a musical interpretation of the Madí artists' aesthetic principles, perhaps the first of such interpretations by a range of other disciplines (ROSSI, 2007: pp. 11-24). ${ }^{12}$

The next year, Koellreutter organized an international course in Teresópolis, at which he invited Tomás Maldonado to give a seminar in industrial design. Argentina did not manage to send artists to the 1st São Paulo Biennial, held in 1951, but concrete works were exhibited at the Biennial's second edition and at the exhibition of the Grupo de Artistas Modernos de la Argentina (GAMA) held at the Museu de Arte Moderna in Rio de Janeiro in August 1953. That same show later traveled to the Stedelijk Museum in Amsterdam.

23 The introduction to the foreign exhibition of the group formed at the initiative of Aldo Pellegrini and in response to his postulates on abstraction was written by Romero Brest, who has gained prestige thanks to his participation on the jury at the 1st São Paulo Biennial in 1951. Significantly, this show provided the group with access to a revered international venue-indeed, Vordemberge-Gildewart gave a speech at the Dutch opening-but in the context of GAMA the concrete artists had to compromise, giving up their orthodox tenets as they shared the exhibition with artists who explored free abstraction.

24 Meanwhile, in 1952, concrete art made its way to Chile on the back of growing interest in innovative architecture (CERTEAU, 2001: pp. 391-425). Both the Universidad Católica de Santiago-which had hired Josef Albers to chair its Art Program-and the Universidad Católica de Valparaíso-where Alberto Cruz Covarrubias had started teaching-attempted to change instruction in art and architecture. Cruz Covarrubias's collaborators included Godofredo Iommi, ${ }^{13}$ who was also interested in tying architecture and poetry. He was the nexus with the Argentine concrete artists.

The Primera Exposición de Arte Concreto was held in the galleries of the Hotel Miramar (today the Sheraton) in Viña del Mar and in the Sala de Exposiciones of the Ministry of 
Education in Santiago. The organization of consecutive exhibitions, as well as a closing lecture, attests to the determination to spread the avant-garde vision.

In mid-1953, thanks to the efforts of Girola, an exhibition of the Milan-based Movimento d'Arte Concreta (MAC), which Girola had come into contact with while in Italy, was held. ${ }^{14}$ That same show also took place at the Hotel Miramar and the Ministry of Education in Santiago (for those shows, Gillo Dorfles wrote the introduction). The "study of the movement of a useless machine" chosen as the image for the cover of the catalogue to the Chilean shows also attests to the ongoing nature of the connections with the Italian group, since that image had been included in MAC's 1952 bulletin, along with a text announcing a show of paintings and useless machines by Munari.

These exchanges meant that Girola traveled to Valparaíso often, and he found a place on the cultural scene there. In March 1956, he was hired by the Architecture Institute of the Universidad Católica de Valparaíso. From there, he developed new visions that quickly led to other collective projects.

\section{THE NEO-CONSTRUCTIVE AVANT-GARDE}

\section{Kinetic Artists at Center Stage}

Before leaving for Paris, Julio Le Parc was active in the art students' protests. On October 3,1955, the student movement occupied the offices of the three public art academies ${ }^{15}$ to demand changes to the curriculum and that the academies be given university status. In addition to occupying the schools, the students looked for other ways to get their demands for the appointment of new administrative authorities and faculty met-all the while trying to keep studying (Rossi: 2013, 38-46) .

At the beginning of the uprising, the students approached some younger professors who were involved in modern art. Antonio Asís remembers that he and some of his classmates reached out to Hlito, Lidy Prati, and Vardanega to invite them to help out with the protests. When he graduated, Asís traveled to France. In 1956, now settled in Paris, he came into contact with Vasarely, Jean Tinguely, Yacoov Agam, Pol Bury, Nicolás Schöeffer, Jesús Rafael Soto, Narciso Debourg, and others.

Luis Tomasello arrived in Paris not long after Asís, and he began working with the Galerie Denise René. The next to arrive, in 1958, were Vardanega and Martha Boto, and in November of that year Le Parc was awarded a fellowship that allowed him to go there as well. Immediately after, Francisco Sobrino arrived, and then Hugo Demarco, Francisco García Miranda, Horacio García Rossi, and Sergio Moyano (ROSSI, 2012a: pp. 47-67). ${ }^{16}$ In July 1960, Le Parc and those artists formed the Centre de Recherche d'Art Visuel, which included as well European artists François Molnar, François Morellet, Nadine Servanes, Joël Stein, and Jean-Pierre Yvaral. In the group's founding statement, its members explained that they set out to delve into their own personal research through group work, thus constructing a space free of aesthetic, social, and economic pressure.

31 The Latin American artists who already formed part of the Parisian kinetic-Op Art avant-garde struggled to get by. Soto made a living playing the guitar in cafés and, soon after arriving in Paris, Asís joined the group of friends that met up after his performances. In the early nineteen-sixties, Asís began helping Soto-who was now 
enjoying a measure of recognition-to prepare works and install exhibitions. He helped him with the show Bewogen Beweging held at the Stedelijk Museum in Amsterdam, and with events in Paris and New York. They would remain friends until the time of Soto's death. Over the course of the sixties, the group gradually worked its way into the scene. The London-based magazine Signals, published from August 1964 and March 1966, covered this group of kinetic artists fairly closely, paying particular attention to the works of the Venezuelans. Of the vibrating works, Signals took particular interest in Asís's grids, though it also published reproductions of Sergio de Camargo's reliefs, Lygia Clark's neo-concrete works, as well as the work of the visual poets and filmmakers (ROSSI, 2012b: pp. 16-28).

Thanks to his friendship with Arden Quin, Asís formed part of the network of artists clustered around the journal Ailleurs. Jean Thiercelin, Volf Roïtman, Jacques Sénelier, and Arden Quin himself sat on the editorial board under the directions of Henri Tronquoy. ${ }^{17}$ Visual poetry played a major role in the magazine in circulation between summer 1963 and winter 1966 starting with its second issue, when Julien Blaine joined the board. ${ }^{18}$ From the outset, Asís was in charge of the photographs and the layout of some of the magazine's covers. On the one hand, then, Arden Quin and Asís worked together on the magazine's covers and illustrations and, on the other, their kinetic works and photograms were featured on its pages. Rich in illustrations, the magazine also published works by Morellet, Vardanega, Sobrino, Le Parc, and Stein.

Ailleurs also reproduced works conceived by Godofredo Iommi in Chile. Indeed, its first issue-illustrated with photographs of Iommi's phalènes-published Iommi's "Lettre de l'Errant" and Arden Quin's poem "L'Aurore des Ages." Godofredo defined his phalènes as the actions through which the poet was able to seize the public space and engage the viewer in play. The name of these actions, in which participants would hear their own words illuminated by poetic language, was taken from the image of a moth that burns in the very light that attracts it. Asís not only attended these performances, but also, on occasion, filmed them.

Girola took part in this forum of exchange while he was in Paris. Back in the early sixties, he had begun to critically rework the avant-garde agenda as his directional and flat works began to include fractured volumes. When he returned to Chile, he formed part of the collective of Latin American and European intellectuals that took part in the Travesía de Amereida (1965), a poetic journey from Tierra del Fuego to Santa Cruz de la Sierra in Bolivia. Envisioned as a means to rediscover the environment, those journeys, during which Girola produced "sculptural signs," became a common practice at the Universidad Católica de Valparaíso's School of Architecture. The signs and works produced outdoors were ephemeral forms that questioned the relationship between man and his environment. Cecilia Brunson understood this proposal as a means to innovate the avant-garde (BRUNSON, 2007: pp. 169/179).

The Groupe de Recherche d'Art Visuel (GRAV) emphasized visual instability. Steadfastly radical and anti-institutional, GRAV encouraged public participation. The work of its members was covered by the art press-the magazine Robho featured their productions as well as a number of controversies in which they were involved-and the group made its way into the international circuit. Its development, though, was not devoid of contradiction and conflict, and GRAV split up after Le Parc won a prize at the 1966 Venice Biennale. ${ }^{19}$ 
36 After the disbandment of GRAV, Argentine artists García Rossi, Demarco, Asis, Leopoldo Torres Agüero, and Armando Durante formed the Groupe Position in order to reactivate the circulation of kinetic art. They stated:

In April 1971, we decided to form a group in light of both how hard the artist's individual struggle is in a society that marginalizes him and of how many new possibilities arise through organic work as a team. ${ }^{20}$

37 In order to foster contacts with galleries, critics, collectors, and viewers, this new group not only resumed a collective practice but also rekindled some of the aims upheld by the original Centre de Recherche and GRAV. Their stated goals included organizing group shows with the advantage of shared funding where the artists themselves would determine how many works each contributed; engaging in joint research and periodic critiques; incorporating the visual arts and architecture; creating a common fund from $5 \%$ of the group members' sales; and financing a shared studio in which there would be a permanent exhibition.

The origin of another attempt to enliven spaces of circulation lay in the $1^{\underline{a}}$ Muestra Internacional "Forma y Espacio," held at the Museo de Arte Contemporáneo in Santiago in 1962. Forma y Espacio was a group of artists from Argentina, Uruguay, and Chile gathered for the show to bolster constructive art. The group returned to avant-garde practices when it issued the Manifiesto de los pintores Constructivos de Argentina, Chile $y$ Uruguay.

39 After the show, the artists in it decided to make their group permanent and planned a next encounter in Argentina. A commission was formed to organize a "biennial." Roles were assigned and agreements made to hold the biennial at the Museo Nacional de Bellas Artes in Buenos Aires. But, as negotiations were underway, Romero Brest was replaced by Samuel Oliver as the director of the museum. Oliver "was not willing to make the Museum's galleries available to an exhibition of painting whose organizing principle held not the slightest interest." ${ }^{21}$ And so the preparations of the would-be biennial were aborted. ${ }^{22}$

\section{Some Closing Considerations}

40 Upon reexamining the contacts in the network that joins the concrete avant-garde of the nineteen-forties and the kinetic avant-garde of the nineteen-sixties, it is clear that the Río de la Plata had a special place on the map of World War II-a conflict that did not extend to its territory. That place contributed to the early emergence of an avantgarde committed to rationality in times of ruin. This particular juncture, specifically 1945 and 1946, witnessed the simultaneous emergence of concrete works in the Río de la Plata and the resurgence and circulation of European work that had been cut off by the war.

41 The synchronicity of the Río de la Plata concrete avant-garde and the widely recognized work of European artists cannot, in my view, be understood outside the framework of politicization in face of worldwide devastation. Traditional art histories, though, have focused more on the problems of artistic language than on the utopian search for hope even before reconstruction got underway. Those histories have been more concerned with tracing the sequences and chains of influence than with problematizing the repetitions between the avant-garde and the neo-avant-garde, as Hal Foster would put it (FOSTER, 2001: pp. 3-36). 
On the one hand, the distance between Latin America and the battlefield provided the region's artists with a common platform ${ }^{23}$ that favored constructivism. On the other, in the wake of the war, there was a clash between the need artists felt to interpret the new problems of the modern world and stymied local art education. For that reason, dissatisfied young artists sought to bring down the status quo for the sake of innovation and exchange.

This map of contacts also lays bare the tension in relation to international centers of legitimation and circulation of modern art. Argentine artists in the kinetic neo-avantgarde looked back to the constructive line, the problem of motion, and the idea of participation central to the artists of the forties, and to that earlier avant-garde's great efforts to gain access to international art centers.

In that framework, Argentine artists not only radicalized their resistance to the art education system, but also moved to Paris and dug in their heels, forming groups and associations and joining international alliances like Nouvelle Tendance. They participated in juried shows and biennials (the Venice Biennale, Documenta in Kassel, the São Paulo Biennial, the Bieniales Americanas de Arte, the Bienal de La Habana, the Festival de Medellín, and others.) without sacrificing their confrontational stance (they took part in debates and discussion forums, the boycott of the São Paulo Biennial, etc.). modalities. To that the words of Frank Popper are relevant, if only partly: "It should come as no surprise that a quartet of Argentine artists brought together to oppose academic instruction arrived in Paris in quick succession in 1958 and 1959 in search of a certain atmosphere" (Popper, 1967). While that statement recognizes the resistance to academic instruction, it fails to see the positive aspects of the student movement. The experience of confrontation and group organization, but also of political engagement, gained during that period proved fundamental to Argentine artists' contributions to GRAV in the tumultuous Parisian scene of the sixties (ROSSI, 2013; pp. 38-46).

The cases of Groupe Position and of Forma y Espacio evidence a return to avant-garde practices in the framework of asymmetric policies that strained the art scene. ${ }^{24}$ Before problems finding a place for themselves, those two groups looked back to avant-garde practices to dislodge the domination of an institutionality that tended to exclude them. At stake in that approach might be, looking to Certeau, the "tricks" of the weak attempting to upset the order constructed by those who hold the power of symbolic and economic legitimation. At play as well, though, is a history of resistances that seems condemned to eternal return.

\section{BIBLIOGRAPHY}

BOURDIEU, Pierre (1995), Las reglas del arte. Génesis y estructura del campo literario, Anagrama, Barcelona. (English title: The Rules of Art: Genesis and Structure of the Literary Field) 
BRUNSON, Cecilia (2007), “Originalidad y vacío: dos preguntas escultóricas”, in Sylvia Arraigada, Brunson C. and Browne, T, Claudio Girola. Tres momentos de arte, invención y travesía 1923/1994, Santiago, Chile, Pontificia Universidad Católica de Chile press.

CERTEAU, Michel de (2001), "De las prácticas cotidianas de oposición" in Modos de hacer: arte crítico, esfera pública y acción directa, Universidad de Salamanca press, Salamanca, pp. 391-425. (English title: The Oppositional Practices of Everyday Life)

DE MAISTRE, Agnès (1996), Carmelo Arden Quin, Demaistre, Nice.

FOSTER, Hal (2001). El retorno de lo real. La vanguardia a finales de siglo, Akal, Madrid. (English title: The Return of the Real: The Avant-Garde at the End of the Century)

GARCÍA, María Amalia (2011). El arte abstracto. Intercambios culturales entre Argentina y Brasil, Siglo XXI, Buenos Aires (English Title: Cultural Crossings: Cultural Exchange Between Argentina and Brazil)

JIMÉNEZ, Ariel (2010). Carlos Cruz Diez En conversación Ariel Jiménez, Fundación Cisneros, New York. (English title: Carlos Cruz-Diez in conversation with Ariel Jimenez)

KRAUSS, Rosalind (1996). La originalidad de la vanguardia y otros mitos modernos, Alianza Forma, Madrid. (English title: The Originality of the Avant-Garde and Other Modernist Myths)

MELÉ, Juan (1999). La vanguardia del cuarenta en la Argentina. Memorias de un artista concreto, Cinco press, Buenos Aires.

PLANTE, Isabel (2013). Argentinos de París. Arte y viajes culturales durante los años sesenta, Buenos Aires, Edhasa.

POPPER, Frank (1967). “García Rossi” in Luz y movimiento (cat. exp.), Galería Rubbers, Buenos Aires.

RODRÍGUEZ, Bélgica (1979). Arte Constructivo Venezolano 1945/65, Génesis y Desarrollo, GAN, Caracas.

ROSSI, M. Cristina (2007). "Vanguardia concreta rioplatense. Acerca del arte concreto y la música" in ICAA Document Project Working Papers, n.․․ 1, International Center for the Arts of the Americas at the Museum of Fine Arts, Houston.

ROSSI, M. Cristina (2010a). “Escritos y testimonios. El caso del 'Manifiesto de cuatro jóvenes"' in VII Jornadas Nacionales de Investigaciones en Arte en Argentina. Los desafíos del arte en el año del Bicentenario," School of Fina Arts, Universidad Nacional de La Plata, La Plata, 2010, CD Rom.

ROSSI, M. Cristina (2010b). Las utopías constructivas en la posguerra rioplatense, doctoral thesis, Universidad de Buenos Aires.

ROSSI, M. Cristina (2012a). “Imágenes inestables. Tránsitos Buenos Aires-París-Buenos Aires” in María José Herrera (ed.), Real/Virtual, Arte cinético argentino en los años sesenta, Museo Nacional de Bellas Artes, Buenos Aires.

ROSSI, M. Cristina (2012b). “Antonio Asís en la trama parisina” in Wechsler, Diana (ed.) Antonio Asís. Un universo vibrante, Sáenz Peña, Universidad Nacional de Tres de Febrero, pp. 16-28.

ROSSI, M. Cristina (2013). “Julio Le Parc y el Movimiento Estudiantil” in Estampa 11, no 2, Universidad Nacional de Cuyo, Mendoza, pp. 38-46,

http://revistas.uncu.edu.ar/ojs/index.php/estampa11/article/view/59

ROSSI, M. Cristina (2018) La revista Arturo en su tiempo inaugural, Fundación Espigas, Buenos Aires, 2018. Available at: http://revistasdeartelatinoamericano.org/items/show/57 
WILSON, Adolfo (2007). Consonancia. La abstracción geométrica en la Argentina y Venezuela. Años 40 y

50, Artesanogroup, Caracas.

\section{ENDNOTES}

\section{NOTES}

On Arturo. Revista de artes abstractas and how it emerged, see: ROSSI, 2018.

2. Bayley, Antonio Caraduje, Simón Contreras, Espinosa, Claudio Girola, Hlito, Iommi, Obdulio Landi, Raúl Lozza, Rembrand Van Dyck Lozza, Maldonado, Alberto Molenberg, Mónaco, Oscar Núñez, Lidy Prati, and Jorge Souza.

3. Arden Quin, Gyula Kósice, Rothfuss, Martín e Ignacio Blaszko Valdo Longo, Diyi Laañ, Steiner, Dieudonné Costes, Raymundo Rasas Pet, Aldo Prior, Sylwan-Joffe Lemme, Esteban Eitler, Paulina Ossona, and others.

4. The artists connected by their travels included Max Bill, Richard Lohse, Camilla Graeser, and Verena Loewensberg in Switzerland; Georges Vantongerloo in Paris; and Max Huber, Bruno Munari, Gianni Dova, Piero Dorazio, Diego Peverelli, Achille Perilli, and Gillo Dorfles in Italy.

5. The declaration held that European influences had not stymied the development of local production but, on the contrary, constituted the "basis for entirely novel discoveries and works." See Arte Nuevo, Salón Kraft, October 30 to November 1, 1947.

6. We extend Rosalind Krauss's conception to the domain of abstraction (KRAUSS, 1996: pp. 289-303).

7. Those students included Mateo Manaure, Alirio Oramas, Perán Erminy, Rubén Núñez, Juan Liscano, Rafael, Pineda, Sergio Antillano, and Alfredo Armas Alfonzo.

8. See "Pintura Abstracta en el Taller Libre de Artes," in Ultimas Noticias, Caracas, 10-25-48.

9. Exhibition catalogue to "José Mimó Mena y el grupo de arte concreto invención de Buenos Aires en el Taller Libre de Pintura," Caracas, 10-24-48.

10. Letter from Del Marle to G. Kosice, París, 1-3-48, photocopy of the manuscript in the Fundación Espigas Archive.

11. In the catalogue, the following artists are named as representing Argentina, though Biedma gave an address in Santiago, Chile; Bresler, Belmonte (sic), Laañ, Kosice, Rasas Pet, and LorinKaldor in Buenos Aires; Pereyra, Rothfuss and Uricchio in Uruguay. See P. Descargues, "Le groupe d'avant-garde Madi" in Arts, París, 23-7-48.

12. "Open Letter to H.J. Koellreutter," Madi Universal, no 4, 1950, pp. 15-16.

13. Godofredo Iommi (Buenos Aires 1917-Viña del Mar 2001) was a poet and university professor, and the uncle of Claudio Girola and Enio Iommi. He went to Chile out of his interest in Vicente Huidobro's creationist poetry.

14. This according to A. Cruz Cobarrubias and F. Kröpfl. In January 1953, a show of the MAC group (formed by Allosia, Biglione, Di Salvatore. Dorfles, Mazzon, Mesciulan, Monnet, Munari, Nigro, and Parisot) was held at the Museu de Arte Moderna in São Paulo, in April 1953 in Buenos Aires under the title "Pintores italianos contemporáneos, grupo m.a.c. de milán," and in August in Chile as "Movimiento Arte Concreta."

15. Translator's note: The three schools were the Escuela de Bellas Artes "Manuel Belgrano," the Escuela Nacional de Bellas Artes "Prilidiano Pueyrredón," and the "Escuela Superior de Belllas Artes "Ernesto de la Cárcova." 
16. Many others remained in Buenos Aires, where they also developed kinetic work-but that is beyond the scope of this paper.

17. A French architect and designer, he was involved in the organization of the Asociación Arte Nuevo in 1955. He participated in Travesía Amereida and, in the sixties, supervised the first industrial design workshops at the Universidad Católica de Valparaíso's School of Architecture.

18. Though interested in poetry, the concrete avant-garde in the Río de la Plata did not develop concrete poetry to the extent that their counterparts in Brazil involved in Noigandres journal did.

19. On Robho, see PLANTE, 2013.

20. Grupo Posición, typewritten, Leopoldo Torres Agüero Archive.

21. See the untitled text[A raíz de la exposición internacional], typewritten, n.d. In 1964, Oliver was an enthusiastic organizer of La inestabilidad, GRAV's first exhibition in Argentina.

22. But the show “Abal, Beloso, Lozza -Exposição comemorativa del IV centenário" was held at the Museu de Arte Moderna in Rio de Janeiro, from September 16 to October 17, 1965.

23. This is even the case in countries that were involved in the war, like Brazil.

24. Though not the only factor, the North American Alliance of Progress had great impact on the art system by fostering funding through private capital. Examples include the General Electric Institute in Montevideo, the Bienales Americanas de Arte in Córdoba, Argentina, and the Instituto Torcuato Di Tella (ITDT) in Buenos Aires.

\section{ABSTRACTS}

The work of Latin American constructive and kinetic artists produced in the nineteen-sixties is well recognized by art histories. It has been the topic of countless exhibitions and enjoyed increasing value on the international art market. Notwithstanding, the valorization of those contributions and their interactions still requires novel visions capable of dislodging crystalized readings. We ask ourselves, then, in what scenes these emerging proposals took shape. How did artists come into contact and engage in exchange? What were their guiding interests?

In this paper, I attempt to retrace some of the paths Argentine constructive artists drew in their interest in communicating their proposals and forging artistic exchanges. In so doing, I seek to shed light on zones neglected by art history's traditional narratives. I attempt to observe the convergences and divergences between the paths drawn by those artists without falling into the notion of subalternity at play in those traditional narratives.

Les propositions des artistes latino-américains qui ont travaillé sur la ligne constructive et cinétique dans les années 60 constituent un chapitre reconnu par les histoires de l'art. D'autant plus que ce mouvement a été légitimé par d'innombrables expositions et par l'appréciation croissante du marché international de l'art. Cependant, l'évaluation de ses contributions et leurs places dans les espaces de négociation exigent, toujours, des vues qui tentent de démanteler les lectures cristallisées. Dès lors, nous demandons: ¿quels ont été les scénarios d'émergence?, ¿comment se sont construits les contacts et les échanges entre artistes? ¿quels intérêts ont guidé leurs travaux?

\section{INDEX}

Mots-clés: ARTE CONCRETO INVENCION - MADI - Groupe de Recherche d'Art Visuel (grav) Groupe Position - $1^{\mathrm{a}}$ Muestra Internacional "Forma y Espacio", Art cinétique - Réseau d'échange Keywords: ARTE CONCRETO INVENCION - MADI - Groupe de Recherche d'Art Visuel (grav) Groupe Position - 1ª Muestra Internacional "Forma y Espacio", Kinetic Art - Exchange network 


\section{AUTHORS}

\section{MARIA CRISTINA ROSSI}

$\mathrm{PhD}$ in art history and theory from the Universidad de Buenos Aires (UBA), where she is Associate Professor of Modern and Contemporary Latin American art. She is Professor at the Universidad Nacional de Tres de Febrero (UNTREF) at Graduate Curatorial Studies. Author of numerous books and articles in academic journals. She is a freelance curator of exhibitions of Latin American art.

ITHA-UBA/IIAC-UNTREF

Centro de Estudios Espigas-IIPC-UNSAM 